\title{
Capital Structure's Dynamic Response to Exogenous Variables: A Case of Listed Manufacturing Firms in Indonesia
}

\author{
Siti Saadah (Corresponding author) \\ Faculty of Economics, Atma Jaya Catholic University \\ Jl. Jenderal Sudirman 51, Jakarta - Indonesia \\ Tel: +81-511-223-365Ｅ-mail: siti.saadah@atmajaya.ac.id \\ Ruslan Prijadi \\ Faculty of Economics, Universitas Indonesia \\ Depok - Indonesia \\ E-mail: ruslan.prijadi@ui.ac.id
}

Received: December 4, 2011

Accepted: January 5, 2012 Published: April 15, 2012

doi: 10.5430/ijfr.v3n2p86

URL: http://dx.doi.org/10.5430/ijfr.v3n2p86

\begin{abstract}
Research on capital structure has been shifting from static to dynamic approaches. This shift is denoted by efforts to verify the presence of optimal leverage and how a firm would adjust to changes in variables that affect the leverage. This research derives an Error Correction Model from a quadratic cost function to investigate the presence of optimal leverage and how a firm adjusts its capital structure toward the optimal one.

This research reveals the existence of the dynamic adjustment process. The negative signs of error correction terms confirm that the firm would have a reversal response to its current leverage position. If it is below the optimal level, the firm would adjust upward; and vice versa. The speed of adjustment are different across industry.

This research confirms the importance of the trade-off and market timing theories in explaining the dynamics of capital structure of manufacturing firms in Indonesia.
\end{abstract}

Keywords: Dynamic Capital Structure, Optimal Leverage, Speed of Adjustment

\section{Introduction}

A firm's decision on capital structure will affect risk and return to shareholders. This is a decision to arrange capital and financial composition to minimize the firm's cost of capital. Current research on how the firm decides on its capital structure is signified by efforts to examine the existence of a target leverage and how the firm moves toward the target when the exogenous variables change.

Research on the target leverage is also an attempt to differentiate two competing theories on capital structure, the trade-off and pecking order theories. Myers (1984) states that the key for differentiating these theories is whether the firm adjusts to optimal capital structure when there are shocks. There have been many efforts to construct theories to explain dynamic capital structure problem; however, there has no theory to be found yet.

Motivated by the same intention, this research adopts a quadratic cost function to give theoretical substance into the dynamics of capital structure. Using this approach, the capital structure dynamics is viewed as a movement of a firm from its disequilibrium state - a condition with suboptimal capital structure - to the target capital structure. Being in the disequilibrium state, the firm has to deal with two types of costs: costs of being in the disequilibrium state (disequilibrium cost) and costs to move from existing state to the equilibrium one (adjustment cost).

The proposed mechanism will explain why the firm needs to adjust closer to its optimal leverage. To maximize the firm's value, the adjustment process should minimize the costs. The adjustment process can be explained by the error correction model (ECM). Whereas many previous researches use the ECM directly, this research adopts the quadratic cost function to rationalize the adjustment process. The empirical model in this research can be used to confirm whether 
a firm will respond to changes in exogenous variables. This model can also estimate the optimal leverage level; thus, predicts distance of the firm's leverage from its optimal value.

This research is able to detect the dynamic adjustment process toward the optimal capital structure. This research reveals another important facts that the trade-off and market timing theories approaches significantly work in explaining behavior of the capital structure movement. This research depicts the difference of speed of adjustment across industry, suggesting that each industry might have different strategies or requirements to fulfill its capital needs. The research is also able to estimate the optimal capital structure of every firm. This research will be a valuable extension to previous research, since there has been no theory used to guide the dynamics of capital structure formation. This research is also the first to derive the ECM dynamic specification from the quadratic cost function.

The remaining of this paper is organized as follows. Section 2 presents the literature review, Section 3 describe the development of analytical model, Section 4 is research methodology, Section 5 highlights the empirical results and discussion, and Section 6 offers conclusion and implications of the research.

\section{Literature Review}

Capital structure theory is attributable to Modigliani and Miller (1958) who claim that, under several assumptions, the capital structure is irrelevant. Relaxing these assumptions mades the capital structure important to the firms and generates two main theories, trade-off and pecking order theories (Elsas and Florysiak, 2008). Furthermore, relaxing the assumption of homogenous expectation has emerged the market timing theory of Baker and Wurgler (2002).

Most recent research on capital structure has shifted from static to dynamic approaches, using various dynamic specifications expected to capture the adjustment toward the target leverage. Using panel data, Kremp et al. (1999) support the existence of the dynamic adjustment in Germany and French. Similarly, De Miguel and Pindado (2001) show that, in Spain, a firm has a target leverage and try to adjust its capital structure to reach the target leverage as fast as possible.

Nishioka and Baba (2004), and Gaud et al. (2005) use the dynamic partial adjustment mechanism (PAM) to find the determinants of capital structure based on trade-off and pecking order theories. The latter suggests that the pecking order and trade-off hypothesis can explain behavior of firm's capital structure in Switzerland. The analysis also shows that the firm has made adjustment to its target leverage.

Using different model, Bontempi (2002) builds dynamic model specification of Error Correction Mechanism (ECM) to investigate the determinants of capital structure based on pecking order and trade-off theories. The trade-off variables include cost of debt financing, cost of equity financing, non-debt tax shield, tangible asset, liquid asset and intangible asset. The join pecking order and trade-off variable is the free cash flow. His ECM dynamic model is able to detect the converging process of capital structure toward its equilibrium stage. However, his model-derived from the Autoregressive Distributed Lag (ARDL) model—is lack of theoretical essence.

\section{Analytical Model}

Dynamic capital structure using Quadratic Cost Function Approach. This research derives ECM through a minimization of the disequilibrium and adjustment costs when the firm moves from current state to its optimal capital structure. The assumptions of this process are:

1. The firm has a target (optimal) leverage, $d_{i t}^{*}$. This assumption is important because the characteristic of dynamic adjustment pattern will depend on the time path from the optimal leverage.

2. A group of variables drawn from trade-off, pecking order and market timing theories are considered to affect effectively the process of achieving optimal leverage target $\left(d_{i t}^{*}\right)$.

Based on the second assumption, the target leverage is stated in long term relation or equilibrium as follows:

$d_{i t}^{*}=a_{0}+a_{1}$ trade $_{i t}+a_{2} f c f_{i t}+a_{3} m b r_{i t}$

where:

trade: a vector of variables included in the first construct (drawn from the trade-off theory);

fcf: a vector of variables included in the second construct (joint variable of the trade-off and pecking order theories);

mbr : a variable represents the market timing theory.

Should there are shocks which affect the leverage, the observed leverage will deviate from the optimal one. The deviation or disequilibrium error (DE) is captured by the following equation: 
$D E=d_{i t}^{*}-\left(a_{0}+a_{1}\right.$ trade $\left._{i t}+a_{2} f f f+a_{3} m b r_{i t}\right)$

At this state, the firm should bear additional costs, i.e., the disequilibrium costs, since it is in disequilibrium stage, and the adjustment cost, since it has to move from its current capital structure. Facing this situation, the firm is assumed to reach equilibrium by minimizing disequilibrium and adjustment costs.

Following the approach developed by Domowitz and Elbadawi (1987) and also Insukindro (1992), a quadratic cost function is formulated as follows:

$C_{i t}=b_{1}\left[d_{i t}-d_{i t}^{*}\right]^{2}+b_{2}\left[(1-L) d_{i t}-c(1-L) \mathbf{Z}_{i t}\right]^{2}$

where:

$Z_{i t}$ - is a vector of exogenous variables;

$\mathrm{L}-$ is a lag operator.

The first component of equation (3) is the disequlibrium cost and the second reflects the adjustment cost. Component $c(1-L) \mathbf{Z}_{i t}$ is inserted as part of the adjustment cost since the observed system is not only in the area around $d_{i t-1}$.

The firm then attempts to minimize $C_{i t}$ with respect to $d_{i t}$ and produces:

$d_{i t}=b d^{*}+(1-b) L d_{i t}+(1-b) c(1-L) \mathbf{Z}_{i t}$

where:

$b=\frac{b_{1}}{b_{1}+b_{2}}$

Equation (4) shows that the actual leverage at t period will be affected by (i) its optimal leverage ratio, (ii) leverage at the previous period, and (iii) the change of exogenous variables that affect the leverage. Since the optimal leverage cannot be observed directly so we could substitute equation (1) on equation (4) and solve for $d_{i t}$ to produce:

$d_{i t}=g_{0}+g_{1}$ trade $_{i t}+g_{2} f c f_{i t}+g_{3} m b r_{i t}+g_{4}$ trade $_{i t-1}+g_{5} f c f_{i t-1}+g_{6} m b r_{i t-1}+g_{7} d_{i t-1}$

After re-parameterization - to avoid level variables which might be non-stationary - the equation becomes:

$$
\begin{aligned}
D d_{i t}= & g_{0}+g_{1} \text { Dtrade }_{i t}+g_{2} D f c f_{i t}+g_{3} D m b r_{i t}+\left(g_{4}+g_{1}\right) L t r a d e_{i t}+\left(g_{5}+g_{2}\right) L f c f_{i t}+ \\
& \left(g_{6}+g_{3}\right) L m b r_{i t}+\left(g_{7}-1\right) L d_{i t} \\
= & g_{1} \text { Dtrade }_{i t}+g_{2} D f c f_{i t}+g_{3} D m b r_{i t}-\left(1-g_{7}\right)\left[\left[L d_{i t}-\frac{g_{4}+g_{1}}{1-g_{7}} L_{t r a d e_{i t}}-\frac{g_{5}+g_{2}}{1-g_{7}} L f c f_{i t}\right.\right. \\
& \left.\frac{g_{6}+g_{3}}{1-g_{7}} L m b r_{i t}-\frac{g_{0}}{1-g_{7}}\right]
\end{aligned}
$$

that can be simplified into:

$D d_{i t}=\alpha_{1}$ Dtrade $_{i t}+\alpha_{2} D f c f_{i t}+\alpha_{3} D m b r_{i t}+\alpha_{4}\left(L d_{i}-\beta_{0}-\beta_{1} L t r a d e_{i}-\beta_{2} L f c f_{i}-\beta_{3} L m b r_{i}\right)$

where:

$$
\begin{array}{llll}
\alpha_{1}=g_{1} & \alpha_{2}=g_{2} & \alpha_{3}=g_{3} & \alpha_{4}=-\left(1-g_{7}\right) \\
\beta_{0}=\frac{g_{0}}{1-g_{7}} ; & \beta_{1}=\frac{g_{4}+g_{1}}{1-g_{7}} ; & \beta_{2}=\frac{g_{5}+g_{2}}{1-g_{7}} ; & \beta_{3}=\frac{g_{6}+g_{3}}{1-g_{7}} ;
\end{array}
$$

Further re-parameterization of equation (7) produces:

$$
\begin{aligned}
D d_{i t} & =\alpha_{4} \beta_{0}+\alpha_{1} \text { Dtrade }_{i t}+\alpha_{2} D f c f_{i t}+\alpha_{3} D m b r_{i t}+\alpha_{4}\left(1-\beta_{1}\right) L t r a d e_{i t}-\alpha_{4}\left(1-\beta_{2}\right) L f c f_{i t} \\
& +\alpha_{4}\left(1-\beta_{3}\right) L m b r_{i t}-\alpha_{4}\left[L_{t r a d e}+L f c f_{i t}+L m b r_{i t}-L d_{i t}\right]
\end{aligned}
$$

Equation (8) is the standard model of the Error Correction Model (ECM), that can be written as:

$$
\begin{aligned}
D d_{i t}= & \gamma_{0}+\gamma_{1} \text { Dtrade }_{i t}+\gamma_{2} D f c f_{i t}+\gamma_{3} D m b r_{i t}+\gamma_{4} \text { Ltrade }_{i t}+\gamma_{5} L f c f_{i t}+\gamma_{6} L m b r_{i t} \\
& +\gamma_{7}\left[\text { Ltrade }_{i t}+L f c f_{i t}+L m b r_{i t}-L d_{i t}\right]
\end{aligned}
$$


The component in the bracket on the right side equation is the Error Correction Term (ECT). Equation (9) is the empirical model of this research. The equation shows that changes in capital structure is partly caused by (i) changes in the predictors and the value of capital structure in previous periods, and the remaining is caused by (ii) the correction on equilibrium error (the deviation of actual leverage from its optimal values) in previous periods.

The speed of the adjustment toward the optimal value is determined by $\gamma_{7}$, the adjustment or error correction term parameter. By combining equations (7), (8), and (9), the adjustment turns into:

$\gamma_{7}=-\alpha_{4}$

$\alpha_{4}=-\left(1-g_{7}\right)$

$\left|g_{7}\right| \prec 1$, necessary condition for stability condition of the difference equation (5)

$\left|g_{7}\right| \prec 1 \rightarrow \alpha_{4}<0$, based on equation (11)

$\alpha_{4}<0 \rightarrow \gamma_{7}>0$, based on equation (10)

Lower $g_{7}$ value indicates that $\left(1-g_{7}\right)$ is closer to 1.00 which implied a faster convergent process to the optimal value. On the other side, $\left(1-\mathrm{g}_{7}\right)$ value approaching 0 denotes slow convergent process.

The equilibrium error can be positive at time t-1, or $\left(L d_{i t}^{*}-L d_{i t}\right)>0$, which means that $d_{i t-1}$ is below its expected value. If in a certain period the actual leverage ratio is below its expected ratio, then there will be response or correction such that $d_{i t}$ will rise in the next period, $D d_{i t}>0$. It also applies if in period t-1 $d_{i t}$ is above its equilibrium value (the actual leverage ratio is above the optimal ratio), this means a negative equilibrium error, and therefore the response or correction will bring $d_{i t}$ down in the next period, $D d_{i t}<0$.

$\gamma_{1}, \gamma_{2}$, and $\gamma_{3}$ are short term coefficients and show the short term effects from all of three constructs on the leverage ratio. From the standard model above we could derive its long term model as follows:

$d_{i t}^{*}=a_{0}+a_{1}$ trade $_{i t}+a_{2} f c f_{i t}+a_{3} m b r_{i t}$

where:

$a_{1}=\frac{\gamma_{4}+\gamma_{7}}{\gamma_{7}} ; a_{2}=\frac{\gamma_{5}+\gamma_{7}}{\gamma_{7}} ; a_{3}=\frac{\gamma_{6}+\gamma_{7}}{\gamma_{7}} ; a_{0}=\frac{\gamma_{0}}{\gamma_{7}}$.

The above equation can be used to estimate the firm's optimal leverage. It also can be used to predict relative distance of the firm's actual leverage from its optimal value.

\section{Research Method}

\subsection{Variables}

Following Bontempi (2002), this research adopts similar constructs and variables that represent major theories of capital structure. The "trade" construct in equation (12) consists of variables that includes in the first group. These variables are generally hypothesized as determinant of optimal leverage in the trade-off theory. These include cost of debt financing (rdf), cost of equity financing (ref), non debt tax shields (ndts), tangible assets (tga), intangible assets (itga) and net working capital (nwc).

Construct $f c f$ consists of variables in the second group. This includes variables that are hypothesized as determinant of optimal leverage and also join variables of the trade-off or pecking order theories. These variables are free cash flow, profitability (cash), tangible investment (tginv), intangible investment (itginv) and change in net working capital (cnwc).

A variable in the third group is hypothesized as determinant of optimal leverage derived from the market timing theory. The variable is the market to book ratio (mbr).

\subsection{Unit of Analysis and Sample}

The unit of analysis of this research is a firm. The sample is manufacturing firms listed in the Indonesia Stock Exchange. The data are extracted from the reports published by the Reference Center of the Capital Market and Financial (internet publication: http://www.idx.co.id.).

The members of the sample are chosen from each subgroup of manufacturing industry. The subsample in every subgroup is determined proportionally. Out of 72 firms, only 53 firms have complete quarterly financial reports for 8 years period (2001-2008); these firms are maintained as members of the sample. Therefore, panel data for further analysis include 1,696 observations. 


\subsection{Estimation Methods}

The processes to build empirical model specification include identification of parameters, selection of structural model and depiction of the variance covariance matrices of the residuals. Based on the empirical model in (9), the endogeneity derived from the dynamic specification is not an issue since there is no lag dependent variables are used as the regressors, and thus, no need to accommodate instrumental variable. The estimation method is chosen from approaches that minimizes $e^{\prime} e=(Y-X \beta)^{\prime}(Y-X \beta)$, the least square approach, or minimizes $\left(X^{\prime} e\right)^{\prime}\left(X^{\prime} e\right)=e^{\prime} X X^{\prime} e$, the generalized method of moment (GMM).

Panel data analysis is applied. Main benefit of panel data (compare to cross section) analysis is that we have a greater freedom in modeling the differences of behavior between firms (Greene, 2000). In capital structure research where the main econometric problem is on the firm heterogeneity, the structural model used in this research is a random coefficient model. The empirical specification (9) is rewritten as follows:

$$
\begin{aligned}
D d_{i t}= & \gamma_{0 i}+\gamma_{1 i} \text { Dtrade }_{i t}+\gamma_{2 i} D f c f_{i t}+\gamma_{3 i} \text { Dmbr }_{i t}+\gamma_{4 i} \text { Ltrade }_{i t}+\gamma_{5 i} L f c f_{i t}+\gamma_{6 i} L m b r_{i t} \\
& +\gamma_{7 i}\left[\text { Ltrade }_{i t}+L f c f_{i t}+L m b r_{i t}-L d_{i t}\right]
\end{aligned}
$$

Unlike the firm's effect model which assumes differences between firms can be interpreted as the differences in the constant, the equation (13) above indicates that all parameters may vary for all firms. Since one of the main problems in panel data analysis is to determine the best structural model, the usual statistical tests will be run to choose the best fitted model. The tests are done to compare the firm effect (in this case, the restricted model) with the random coefficient model (unrestricted model).

\section{Results and Discussion}

\subsection{The Changes of Leverage}

The leverage movement, measured by debt ratio (dr) and its changes (dr1), during the observation periods (Quarter I of 2001 until Quarter IV of 2008) is shown in Figure 1.

The chart indicates that the leverage movement is relatively stable except for periods between 2004 and 2005. The leverage ratio converges from time to time. A period when the average leverage ratio is high (low) tends to be followed by a downward (upward) movement to moderate the leverage level in the following period.

The above mean reversion pattern can be explained as follows. Lemmon et al. (2008) find that the convergence of leverage is caused by the role of leverage as determinant of a firm's net issuance decisions. Firm's securities issuance report indicates that debt policy is an important device to control the firm's leverage. The existence of transitory component show that dynamic specification is needed to examine the capital structure behavior.

\subsection{Estimation of the Dynamic Capital Structure}

In this research, capital structure behavior is analyzed using dynamic model, built from main capital structure theories. By using random coefficient model, the equation can be partitioned according to its original theories as follows:

$$
\begin{aligned}
D d_{i t} & =\gamma_{0 i}+\gamma_{11 i} \operatorname{Drdf}_{i t}+\gamma_{12 i} \text { Dref }_{i t}+\gamma_{13 i} \text { Dndts }_{i t}+\gamma_{14 i} \text { Dtga }_{i t}+\gamma_{15 i} \text { Ditga }_{i t}+\gamma_{16 i} \text { Dnwc }_{i t}+ \\
& \gamma_{21 i} \text { Dcash }_{i t}+\gamma_{22 i} \text { Dtginv }_{i t}+\gamma_{23 i} \text { Ditginv }_{i t}+\gamma_{2 i} D \Delta n w c+\gamma_{3 i} \text { Dmbr }_{i t}+\gamma_{41 i} \text { Lrdf }_{i t}+\gamma_{42 i} \text { Lref }_{i t}+ \\
& \gamma_{43 i} \text { Lndts }_{i t}+\gamma_{44 i} \text { Ltga }_{i t}+\gamma_{45 i} \text { Litga }_{i t}+\gamma_{46 i} \text { Lnwc }_{i t}+\gamma_{51 i} \text { Lcash }_{i t}+\gamma_{52 i} \text { Ltginv }_{i t}+ \\
& \gamma_{53 i} \text { Litginv }_{i t}+\gamma_{6 i} \text { Lmbr }_{i t}+\gamma_{7 i}\left[\text { Ltrade }_{i t}+\operatorname{Lfc}_{i t}+\operatorname{Lmbr}_{i t}-L d_{i t}\right]
\end{aligned}
$$

where:

$D$ : difference operator;

$L$ : lag operator;

$d_{\mathrm{it}}$ : debt ratio of firm $\mathrm{i}$ at quarter $\mathrm{t}$.

Equation (14) is estimated using weighted least square procedures and generalized method of moment. The results show that the weighted least square has better abilities in explaining the capital structure behavior. Furthermore, the results of Wald test conclude that the random coefficient model is better compared to the firm's effect model. 


\subsection{Adjustment toward the Optimal Leverage}

The presence of the dynamic adjustment process is revealed by the coefficients of error correction term (ECT) or the estimate of $\gamma_{7 i}$ in equation (14). Each coefficient represents one firm. As expected, all ECT coefficients, except for three firms, have negative signs or $0<E C T<1$. Negative $E C T$ coefficients relates to positive sign of parameters in (14). The positive sign implies that if during certain periods when the firm's actual leverage ratio is below the optimal ratio (positive equilibrium errors) then the response or correction is to increase the $d_{i t}$ (actual leverage ratio) in the following period, or $D d_{i t}>0$. Vice versa, if during certain periods $d_{i t}$ is above its optimal ratio, the response will bring $d_{i t}$ down in the following period, or $D d_{i t}<0$. Positive sign of parameter $\gamma_{7}$ clarifies that if the firm capital structure deviates from its optimal level due to exogenous variables pressure, then there will be adjustment mechanism done by the firm to return its optimal level. This also confirms that the short run dynamic adjustment from actual capital structure will converge to the optimal capital structure.

Referring to Salmon (1982), there are two possible explanations why some firms have positive ECT coefficients (or negative $\gamma_{7 i}$ coefficient). First, perhaps these firms do not have target leverage to be reached so the ECM cannot explain their capital structure behavior. Second, although the firm may have the target leverage but the time path toward the optimal leverage may not coincide with the pattern as assumed in this research.

The tests on parameter $\gamma_{7}$ to confirm the existence of dynamic adjustment are shown in the Table 1. Figures in that table show that almost all ECT coefficients are statistically significant. The positive and significant coefficients denote the firm's efforts to move toward the target leverage when there are changes on exogenous variables. The tests also support the existence of target leverage as hypothesized by the trade-off theory. These findings are in accordance with previous research in many countries, like Kremp et al (1999), De Miguel and Pindado (2001), Ozkan (2001), Bontempi (2002), Nishioka and Baba (2004), Gaud et al (2005), Flannery and Rangan (2006), Huang and Ritter (2008), Faulkender, et al. (2008), Lemmon, Roberts, and Zender (2008). Their research supports the presence of the target leverage. More importantly, their research shows that individual firm makes adjustment to the targeted leverage at different speed of adjustment. Their research also show that firms in Spain, Germany, England, and US need 2 until 4.76 years, in average, to fully adjust to the target capital structure.

Using Wald test, this present research also finds that the average speed of adjustments is significantly different across industry, as shown in Table 2.

Table 2 shows that when the actual leverage deviates from its optimal value, cigarette, pharmaceutical and household industry is the fastest industries doing the adjustment. In average it needs 2.25 quarters to reach the optimal debt ratio, or the gap between the actual and the optimal leverage ratio can be closed in 2.25 quarters. Infrastructure industry is the sluggish one, it needs 5.05 quarters. Property, real estate and construction need 2.56 quarter, textile and garment industries need 4.12 quarter, basic and primary industries 4.82 quarter, electronic and food and beverage industries need 5.04 and 5.98 quarter, respectively.

The longer the time is needed to reach the optimal leverage the longer is the firm in the disequilibrium state, which will have an effect on the disequilibrium cost. In the situation where the actual leverage is lower than the optimal leverage, sluggish adjustment process will make the process longer and cause higher opportunity cost borne by the firm (the firm losses the chance to maximize tax shield benefits). Vice versa, when the actual leverage is higher than the optimal leverage, slow adjustment process will cause longer time to reach equilibrium and make the firm suffers financial distress longer.

Based on the short term model developed in this research, the optimal leverage can be estimated using the long term equation in (12). The estimates by industry are as follows. Cigarette, pharmacies and household industry's optimal leverage is $65.4 \%$, food and beverages is $68.9 \%$, infrastructure is $78.0 \%$, property and real estate is $69.3 \%$, textile and Garment is $71.3 \%$, various industries is $70.5 \%$, basic and primer industries is $69.4 \%$, and electronic is $69.3 \%$. The findings on the speed of adjustment and the estimated optimal leverage figures of the firms are among the contribution of this research to enrich the research on capital structure in Indonesia.

\subsection{Determinants of Capital Structure}

The estimated ECM parameters above can be interpreted differently as the determinants of capital structure. Based on panel data analysis, the short term variables that significantly affect the capital structure movement are non debt tax shield, tangible asset, intangible asset and net working capital (all are derived from trade-off theory), and market to book ratio (from market timing theory). Table 3 shows the details of the regression results.

The negative sign of non debt tax-shield (ndts) coefficient supports the trade-off theory that the non debt tax-shield could reduce the fiscal benefit of the debt. Increasing non debt tax-shield will reduce the firm debt ratio. DAngelo and 
Masulis (1980) examine the optimal capital structure model by incorporating the effect of non debt related corporate tax shield. They argue that the tax benefit from depreciation could replace the benefit from debt financing. Firm with large non debt tax shield will have less debt in its capital structure.

The negative sign of tangible asset coefficient confirms that higher tangible assets causes higher non debt tax shield. This is typical of research on manufacturing firms. As DAngelo and Masulis (1980) said, the non-debt tax shield could substitute the benefit of debt financing. Therefore, firms with high non debt tax-shield will have less debt in their capital structure.

The negative sign of coefficient of the intangible asset (itga) supports the trade-off theory. Following Harris and Raviv (1990), the intangible assets are assets with low liquidation value. Firm holding assets with low liquidation value will get fewer benefits from the liquidation (when the firm defaults), so higher debt is not preferred because of the pressure for liquidation increases when the firm defaults. Titman and Wessels (1988) use intangible asset as an indicator for asset collateral value. They say that the collateral value is negatively related with firm's intangible asset. Firm with sizeable intangible asset usually has a low collateral value. This firm will reduce debt in their capital structure.

The negative sign of the net working capital coefficient does not support the trade-off theory which hypothesized that a firm with higher net working capital has a larger debt capacity. This is because the assets can easily be liquidated and offer high liquidation value. Tangible asset (tga) and net working capital (nwc) are assets with high liquidation value. Harris and Raviv predict that firm possessing more assets with high liquidation value will use more debt. This is because ownership of such assets will support debt's role in reducing conflict between manager and shareholder. However, in this research, the negative sign indicates that the firms do not utilize their liquid asset (that might be used to increase debt level) to reduce the conflict between manager and shareholder.

The negative sign of the market to book ratio (mbr) verifies that the market timing theory developed by Baker and Wurgler (2002) also contributes in explaining the movement of capital structure. In a short term, the high market valuation reduces leverage. In this research, the test of market valuation's persistent effects on leverage follows that of Huang and Ritter (2008) who also use the speed of adjustment figures. Since the firms do not instantly adjust their leverage when there are shock on its capital structure, this confirm that the changes in leverage predictors (including the market valuation) will have a persistent impact on the leverage. This research with an ECT coefficient of 0.27 shows that market to book ratio have a long- rather than short-time impacts on the leverage.

\section{Conclusion}

Making the right decision in capital structure is a crucial to any firm. Recent research on firm's capital structure is denoted by efforts to investigate the presence of the optimal capital structure and how the firm responses to changes in exogenous variables. This research, using the quadratic cost function — a basis for the error correction model—is able to explain how the firm adjusts from its existing toward the optimal leverages.

The existence of the optimal capital structure is the notion to differentiate two competing theories, i.e., the trade-off versus pecking order theories. This present research detects the dynamic adjustment process toward the optimal capital structure; hence, this research supports the existence of target leverage as hypothesized in the trade off theory. The results are in accordance with research done in many countries, such as Kremp et al (1999), De Miguel and Pindado (2001), Okzan (2001), Bontempi (2002), Nishioka and Baba (2004), Gaud et al (2005), Flannery and Rangan (2006), Huang and Ritter (2008), Faulkender et al (2008), Lemmon, Roberts and Zender (2008).

This research reveals another important notions that the trade-off and market timing theories are significantly work in explaining behavior of the capital structure movement. This is similar to that of Huang and Ritter (2008), who show that no single theory can solely explain all of time series and cross sectional patterns of capital structure. The findings also support Myers (2003) statement that joining theories above are needed to explain the capital structure.

This research depicts the difference of speed of adjustment across industry. The fastest adjustment is cigarettes, pharmaceutical and household industries. Although this is not the main objective of this research, this suggests that each industry might have different strategy to fulfill its capital or equity needs, or being in disequilibrium may cost the firm differently that they are better off switching faster or slower to its individual optimal capital structure. The research is also able to estimate the optimal capital structure of every firm.

Information on estimated speed of adjustment and optimal capital structure bring important managerial implications, both for cash management and investment decisions. A firm with lower than expected capital structure cannot optimally utilize its tax-shield and debt's controlling role. This firm, especially the one with low growth, need to be very careful in managing its cash flow not to spend in suboptimal investment projects. A firm with higher than expected capital structure must be aware of high financial distress pressure, which in turns, might raise the conflict between the debt- and 
share-holders. Share-holders tend to execute strategies that are profitable for themselves but decline firm's value in general. They may encourage to execute risky projects expecting most of the profits should there be a rise in firm's value. But, they may encourage to underinvestment worrying that the new investments tend to benefit the bondholders alone.

\section{References}

Baker, M. \& Wurgler, J. (2002). Market Timing and Capital Structure. The Journal of Finance, Vol.57 No. 1, pp. 1-32. http://dx.doi.org/10.1111/1540-6261.00414

Bontempi, M. E. (2002). The Dynamic Specification of the Modified Pecking Order Theory: It's Relevance to Italy. Empirical Economics, No.27, pp. 1-22. http://dx.doi.org/10.1007/s181-002-8356-9

De Miguel, A., \& Pindado, J. (2001). Determinants of Capital Structure: New Evidence from Spanish Panel Data. Journal of Corporate Finance, Vol.7, pp.77-99 http://dx.doi.org/10.1016/S0929-1199(00)00020-1

DeAngelo, H., \& Masulis, R. (1980). Optimal Capital Structure Under Corporate and Personal Taxation. Journal of Financial Economics, No.8, pp. 3-29. http://dx.doi.org/10.1016/0304-405X(80)90019-7

Domowitz, I. \& Elbadawi, L. (1987). An Error Correction Approach to Money Demand: The Case of the Sudan. Journal of Development Economics, No. 26, pp. 257-275. http://dx.doi.org/10.1016/0304-3878(87)90029-0

Elsas, Ralf, \& Florysiak, D. (2008). Empirical Capital Structure Research: New Ideas, Recent Evidence, and Methodological Issues. Discussion Paper, Institute for Finance and Banking, Munich, Germany.

Faulkender, Michael, Mark J. Flannery, Kristine Watson Hankins, \& Jason M. Smith. (2008). Do Adjustment Cost Impede the Realization of Target Capital Structure. Working Paper, 2008.

Flannery, M. J. \& Rangan, K.P. (2006). Partial Adjustment toward Target Capital Structure. Journal of Financial Economics, Vol.79, pp.469-506. http://dx.doi.org/10.1016/j-jfineco.2005.03.004

Gaud, Philippe, Elion Jani, Martin Hoesli \& Andre Bender. (2005). Capital Structure of Swiss Companies: an Empirical Analysis Using Dynamic Panel Data. European Financial management, Vol.11, No. 1, pp.51-69. http://dx.doi.org/10.1111/j.1354-7798.2005.00275.x

Greene, W. H. (2000), Econometric Analysis, $4^{\text {th }}$ edition, Prentice Hall.

Harris, Milton, \& Arthur Raviv. (1991). The Theory of Capital Structure. The Journal of Finance, Vol.46, No.1, pp. 297-334. http://dx.doi.org/10.2307/2328697

Harris, Milton, \& Raviv, A. (1990). Capital Structure and the Informational Role of Debt. The Journal of Finance, Vol.45, pp. 321-349. http://dx.doi.org/10.2307/2328660

Huang, Rongbing, \& Jay R. Ritter. (2008). Testing Theories of Capital Structure and Estimating the Speed of Adjustment. The Journal of Financial and Quantitative Analysis, June 2008.

Insukindro. (1992). Dynamic Specification of Demand for Money: A Survey of Recent Development. Jurnal Ekonomi Indonesia, No.1, pp. 8-23.

Kremp, E., Stoss E., \& Gerdesmeier, D. (1999). Estimation of a Debt Function: Evidence from French and German Firm Panel Data", in Gaud, Philippe, Elion Jani, Martin Hoesli and Andre Bender. (2005). Capital Structure of Swiss Companies: an Empirical Analysis Using Dynamic Panel Data. European Financial management, Vol.11, No. 1, pp.51-69. http://dx.doi.org/10.1111/j.1354-7798.2005.00275.x

Lemmon, M. L., Roberts, M. R. \& Zender, J. F. (2006). Back to the Beginning: Persistence and the Cross-Section of Corporate Capital Structure. The Journal of Finance, 2006.

Modigliani, F. \& Miller, M. (1958). The Cost of Capital, Corporation Finance and the Theory of Investment. The American Economic Review, Vol.48, No.3, pp. 261-297.

Myers, S. C. (1984). The Capital Structure Puzzle. Journal of Finance, Vol.39, No.3, pp. 575-592. http://dx.doi.org/10.2307/2327916

Nishioka, S. \& Baba, N. (2004). How Far Has the Reduction of Excess Leverage Progressed in Japan?, Bank of Japan Working Paper Series, No.04-E-16.

Ozkan, A. (2001). Determinants of Capital Structure an Adjustment to Long Run Target: Evidence from UK Company Panel Data. Journal of Business Finance and Accounting, Vol.28, pp. 175-199. http://dx.doi.org/10.1111/1468-5957.00370 
Salmon, M. (1982). Error Correction Mechanisms. The Economic Journal, Vol.92. No. 367, pp. 615-629. http://dx.doi.org/10.2307/2232553

Titman, S., \& Wessels, R. (1988). The Determinants of Capital Structure Choice. The Journal of Finance, Vol.43, No.1, pp.1-19. http://dx.doi.org/10.2307/2328319

Table 1. ECT Coefficient for Companies in Research Sample

\begin{tabular}{|c|c|c|c|c|c|}
\hline Koefisien & Identifier & $E C T$ & Koefisien & Identifier & $E C T$ \\
\hline $\mathrm{C}(24)$ & AMFG & $-0.065737 * *$ & $\mathrm{C}(51)$ & INTP & $-0.049320 *$ \\
\hline $\mathrm{C}(25)$ & ANTM & $-0.205088 * *$ & $\mathrm{C}(52)$ & ISAT & $-0.467764 * *$ \\
\hline$C(26)$ & ARNA & $-0.293713 * *$ & $C(53)$ & KDSI & $-0.284470 * *$ \\
\hline $\mathrm{C}(27)$ & ASGR & $-0.365164 * *$ & $\mathrm{C}(54)$ & KLBF & 0.232778 \\
\hline $\mathrm{C}(28)$ & ASII & $-0.118990 * *$ & $\mathrm{C}(55)$ & KPIG & $-0.358367 * *$ \\
\hline $\mathrm{C}(29)$ & AUTO & $-0.472825 * *$ & $\mathrm{C}(56)$ & LMPI & $-0.253857 * *$ \\
\hline $\mathrm{C}(30)$ & BATA & $-0.538797 * *$ & $\mathrm{C}(57)$ & LPCK & $-0.575453 * *$ \\
\hline $\mathrm{C}(31)$ & BIPP & -0.085254 & $\mathrm{C}(58)$ & MIRA & $-0.514658 * *$ \\
\hline $\mathrm{C}(32)$ & BRNA & $-0.350318 * *$ & $\mathrm{C}(59)$ & MLPL & -0.058114 \\
\hline $\mathrm{C}(33)$ & BUMI & $-0.321692 * *$ & $\mathrm{C}(60)$ & MTDL & $-0.180197 * *$ \\
\hline $\mathrm{C}(34)$ & CENT & $-0.190701 * *$ & $\mathrm{C}(61)$ & NIPS & $0.316354^{*}$ \\
\hline$C(35)$ & CMNP & $-0.189615^{* *}$ & $\mathrm{C}(62)$ & PBRX & $-0.113516 * *$ \\
\hline $\mathrm{C}(36)$ & CTRS & $-0.213029 * *$ & $\mathrm{C}(63)$ & PTRO & $-0.088234^{*}$ \\
\hline $\mathrm{C}(37)$ & DART & $-0.669144 * *$ & $\mathrm{C}(64)$ & RDTX & $-0.232498 * *$ \\
\hline $\mathrm{C}(38)$ & DAVO & -2.240945 & $C(65)$ & RICY & $-0.087025^{*}$ \\
\hline $\mathrm{C}(39)$ & DUTI & $-0.529450 * *$ & $\mathrm{C}(66)$ & RIGS & $-0.180086^{* *}$ \\
\hline $\mathrm{C}(40)$ & DYNA & $-0.119706^{* *}$ & $\mathrm{C}(67)$ & RMBA & $-0.231420 * *$ \\
\hline $\mathrm{C}(41)$ & ELTY & $-0.349693 * *$ & $\mathrm{C}(68)$ & SMAR & -0.117473 \\
\hline $\mathrm{C}(42)$ & GDYR & -0.028138 & $\mathrm{C}(69)$ & SMCB & $-0.244130 * *$ \\
\hline $\mathrm{C}(43)$ & HDTX & $-0.399567 * *$ & $\mathrm{C}(70)$ & SMGR & $-0.154359 * *$ \\
\hline Koefisien & Identifier & $E C T$ & Koefisien & Identifier & $E C T$ \\
\hline $\mathrm{C}(44)$ & HITS & $-0.253293 * *$ & $\mathrm{C}(71)$ & SSIA & $-0.355521 * *$ \\
\hline $\mathrm{C}(45)$ & HMSP & $-0.381655^{* *}$ & $\mathrm{C}(72)$ & TBLA & $-0.184997 * *$ \\
\hline $\mathrm{C}(46)$ & IGAR & -0.207767 & $\mathrm{C}(73)$ & TCID & $-0.658641 * *$ \\
\hline $\mathrm{C}(47)$ & IKAI & $-0.279527 * *$ & $\mathrm{C}(74)$ & TRST & $-0.343714 * *$ \\
\hline $\mathrm{C}(48)$ & INCI & $-0.252754 * *$ & $\mathrm{C}(75)$ & UNVR & $-0.507846^{* *}$ \\
\hline $\mathrm{C}(49)$ & INDF & $-0.198715^{*}$ & $\mathrm{C}(76)$ & ZBRA & $-0.159194 * *$ \\
\hline $\mathrm{C}(50)$ & INDR & $-0.443812 * *$ & & & \\
\hline
\end{tabular}

Source: Estimation results (2011)

\footnotetext{
** Significant at $\alpha=5 \quad *$ Significant at $\alpha=10 \%$
}

Table 2. The Average of ECT Coefficient for Industries Group

\begin{tabular}{|c|c|}
\hline Industries & Average ECT \\
\hline Cigarette, Pharmaceutical, Household Industry & -0.4449 \\
\hline Properties, Real Estate and Construction & -0.3907 \\
\hline Textile and Garment & -0.3025 \\
\hline Various Industries & -0.2422 \\
\hline Basic and Primary Industry & -0.2074 \\
\hline Electronic Industries & -0.1985 \\
\hline Infrastructure & -0.1979 \\
\hline Food and Beverages & -0.1671 \\
\hline
\end{tabular}

Source: Estimation results (2011). 
Table 3. Coefficient Marked for Predictor of Debt Ratio

\begin{tabular}{|c|c|}
\hline Debt RatioPredictor & Coefficient \\
\hline $\mathrm{C}(2)-$ profitability (cash) & + \\
\hline $\mathrm{C}(3)-\operatorname{cost}$ of debt $(r d f)$ & - \\
\hline $\mathrm{C}(4)-$ cost of equity (ref) & + \\
\hline $\mathrm{C}(5)-$ non debt tax shield (ndts) & $(* *)$ \\
\hline $\mathrm{C}(6)-$ tangible assets (tga) & $(* *)$ \\
\hline $\mathrm{C}(7)$ - intangible assets (itga) & $(* *)$ \\
\hline $\mathrm{C}(8)$ - net working capital (nwc) & $(* *)$ \\
\hline $\mathrm{C}(9)$ - tangible investment (tginv) & + \\
\hline $\mathrm{C}(10)$ - intangible investment (itginv) & - \\
\hline $\mathrm{C}(11)$ - change in net working cap (cnwc) & + \\
\hline $\mathrm{C}(12)-$ market to book ratio $(\mathrm{mbr})$ & $(*)$ \\
\hline
\end{tabular}

(**) significant at $\alpha=5 \%$

(*) $\quad$ significant at $\alpha=10 \%$

Source: Estimation results (2011).

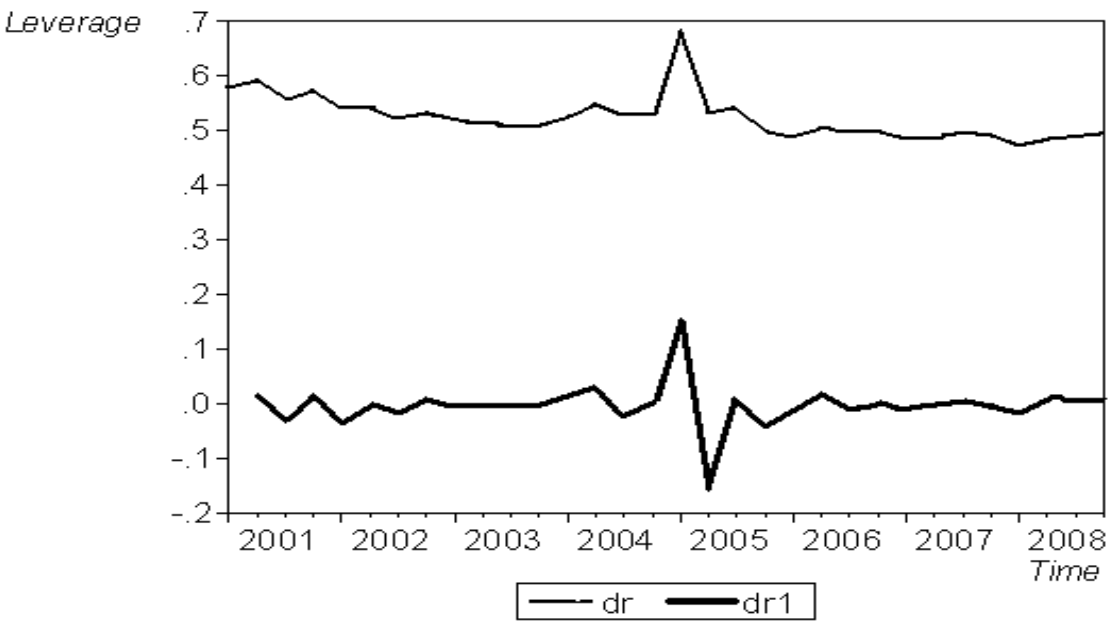

Figure 1. Average Leverage Ratio and its change 